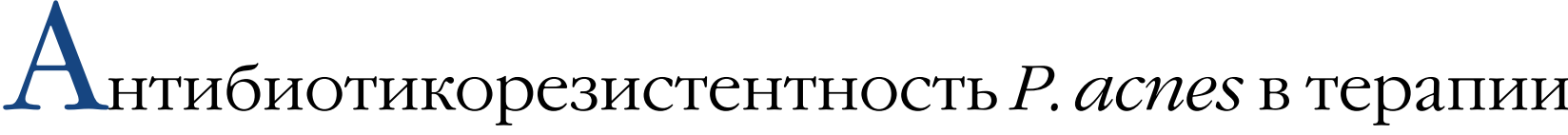 акне. Пути решения проблемы
}

\author{
Н.Н. Мурашкин
}

МАОУ ВПО Краснодарский муниципальный медицинский институт высшего сестринского образования 350063, г. Краснодар, ул. Комсомольская, 46

Представлены причины и частота развития резистентности $P$. acnes к антибиотикотерапии у больных акне.

Рассмотрены стратегия и тактика врача по ограничению распространения антибиотикорезистентности P. acnes.

Обсуждается важная роль бензоила пероксида и синергетический эфффект готовой комбинации адапален/бензоила пероксид в преодолении устойчивости P. acnes и достижении эффективности лечения.

Ключевые слова: антибиотикорезистентность, P. acnes, бензоила пероксид, адапален.

Контактная информация: m_nn2001@mail.ru. Вестник дерматологии и венерологии 2013; (6): 128_131.

\section{Antibiotic resistance of $P$. acnes in the treatment of acne. Ways for solving the problem}

\author{
N.N. Murashkin
}

Krasnodar Municipal Medical Institute of Higher Education for Nurses

Komsomolskaya str., 46, Krasnodar, 350063, Russia

\section{The author describes the reasons and frequency of antibiotic resistance of $P$. acnes in acne patients. He reviews the strategy and methods for doctors to inhibit the prevalence of antibiotic resistance of $P$. acnes. The article discusses the important role of benzoyl peroxide and synergistic effect of the combination of adapalene and benzoyl peroxide in the finished form to overcome the antibiotic resistance of $P$. acnes and ensure the treatment efficacy.}

Key words: antibiotic resistance, $\boldsymbol{P}$. acnes, benzoyl peroxide, adapalene.

Corresponding author: m_nn2001@mail.ru. Vestnik Dermatologii i Venerologii 2013; 6: 128_131.

Propionibacterium acnes ( $P$. acnes) является ключевым бактериальным агентом, определяющим инициацию воспалительного процесса в сально-волосяном фолликуле при акне. P. acnes - грамположительная липофильная палочка, фракультативный анаэроб. С одной стороны, P. acnes стимулируют выработку провоспалительных цитокинов, которые обусловливают хемотаксис в ткани иммунокомпетентных клеток, фрормирующих перифолликулярный инфильтрат [1]. С другой стороны, они стимулируют микрокомедонообразование за счет образования биопленки, посредством которой происходит клейкое слипание корнеоцитов, приводящее к закупорке устья волосяного фолликула [2]. Таким образом реализуются хорошо известные звенья патогенеза этого заболевания: гиперпродукция кожного сала гиперплазированными сальными железами, избыточная бактериальная колонизация, воспаление и фолликулярный гиперкератоз. В этой связи одним из методов таргетного воздействия в терапии данного состояния издавна является антибиотикотерапия. Антибиотики при акне демонстрируют антимикробный и противовоспалительный эффекты и дей- 
ствуют в двух направлениях: уменьшают колонизацию $P$. acnes [3] и ингибируют ассоциированную с $P$. acnes продукцию медиаторов воспаления [4].

Однако со временем отмечено увеличение числа штаммов $P$. acnes, резистентных к антибиотикам. Так, в исследованиях J. Leyden в 1976 г. не было зарегистрировано ни одного случая антибиотикорезистентных штаммов $P$. acnes при обследовании 1000 пациентов с акне. Через 35 лет, в 2011 г., в исследовании этого же ученого показана $100 \%$ устойчивость $P$. acnes к эритромицину, в $20 \%$ случаев - резистентность к клиндамицину, а в $36 \%$ случаев к клиндамицину отмечалась умеренная чувствительность [4].

Первое сообщение об идентификации резистентных $P$. acnes к эритромицину и клиндамицину опубликовали в 1979 г. W. Crawford и соавт. [5]. В дальнейшем сообщения о комбинированной резистентности $P$. acnes к эритромицину и клиндамицину стали появляться в всем мире, при этом количество таких штаммов возросло с 20\% в 1978-1979 гг. до 72,5\% в 1995 г. Кроме того, показано развитие этой перекрестной резистентности уже через 8 нед. монотерапии наружным антибактериальным препаратом (клиндамицином или эритромицином) [6].

Указанные фракты имеют научное объяснение. Как известно, эритромицин и клиндамицин относятся соответственно к группе антибиотиков макролидов и линкозамидов. Основной мишенью действия макролидов и линкозамидов является $50 \mathrm{~S}$ субъединица бактериальной рибосомы. Несмотря на различия в структуре, эти антибиотики имеют общий участок связывания с рибосомой. Длительное повсеместное использование топических и оральных антибиотиков для лечения акне привело к появлению мутантных штаммов $P$. acnes с измененным геномом. Сформировались потенциально патогенные бактерии, имеющие, подобно патогенным стафилококкам и стрептококкам, гены антибиотикорезистентности $[4,5]$. Устойчивость $P$. acnes к антибиотикам обусловлена способностью отдельных штаммов метилировать мишени, на которые действуют макролиды и линкозамиды. Именно этим объясняется тот фракт, что развитие антибиотикорезистентности в отношении антибактериальных препаратов этих групп, как правило, является перекрестным.

Исходя из вышесказанного, логичным будет предположить уменьшение клинической эфффективности препаратов на основе эритромицина и клиндамицина в связи с широко распространенной у $P$. acnes устойчивостью к ним. Кроме того, отдавая предпочтение антибактериальной терапии при акне, врач должен учитывать тот фракт, что организм человека представляет собой единую биосистему, воздействие на один элемент которой может приводить к системным изменениям, затрагивающим весь организм. В этой связи примечательными являются исследования J. Leyden и соавт., анализировавших эфффекты действия топиче- ских и оральных антибиотиков на орофарингеальную микрофрлору пациентов с акне [4]. Оказалось, что для пациентов, получавших антибиотики, риск колонизации стрептококками группы А (Streptococcus pyogenes) в 3 раза больше по сравнению с теми, кому не проводилась терапия антибиотиками.

В 85\% случаев культуры Streptococcus pyogenes от пациентов, использовавших в лечении антибиотики, оказались устойчивы как минимум к одному антибиотику тетрациклинового ряда, в то время как у пациентов, не получавших антибиотикотерапию, этот показатель составил 20\% [7]. Данный факт объясняется феноменом трансдукции, суть которого заключается в переносе части ДНК от одного рода бактерий другому. Таким образом мутантная часть генома $P$. acnes - плазмида антибиотикорезистентности передается бактериям рода Streptococcus [7, 8]. Следует отметить, что этот механизм является универсальным для всех бактерий и передача мутантного генетического материала возможна также другим штаммам микроорганизмов [8].

Подобным образом действуют и топические антибиотики. Продемонстрировано, что антибиотики для наружного применения оказывают воздействие на микрофрлору отдаленных от очагов поражения участков кожи, т. е. на участках кожного покрова за пределами нанесения. Последствием этого является возникновение резистентных к эритромицину и клиндамицину штаммов микроорганизмов, что становится возможным посредством прямой инокуляции бактерий либо через системную абсорбцию антибиотиков.

Так же как и пероральные аналоги, топические антибиотики могут изменять микробный баланс посредством избирательного уничтожения определенных бактерий, позволяя процветать, например, таким штаммам, как Streptococcus pyogenes, чего в норме не наблюдается.

Современные научные изыскания наглядно демонстрируют, что при использовании топического эритромицина увеличивается контаминация резистентным коагулазанегативным стафилококком как кожи, так и всего организма [9-12].

В другом исследовании К. Harkaway и соавт. показали, что аэробная микрофрлора, преимущественно эпидермальный стафилококк, почти полностью устойчива к эритромицину и частично устойчива к клиндамицину и тетрациклину спустя 12 нед. антибиотикотерапии [9].

Важные данные также приводят B. Vowels и соавт., которые обнаружили, что концентрация устойчивых микроорганизмов возвращается к исходным показателям лишь через 6 нед. после прекращения использования топических антибиотиков [10].

Таким образом, нарастающая распространенность резистентных форм $P$. acnes влечет за собой достаточно серьезные последствия:

1) снижение клинического ответа на антибактериальную терапию; 
2) потенциальное увеличение патогенности $P$. acnes;

3) передачу антибиотикорезистентных свойств более патогенным микроорганизмам (стафилококкам, стрептококкам и др.).

\section{Стратегия по ограничению распространения антибиотикорезистентности $\boldsymbol{P}$. acnes}

Следует констатировать тот фракт, что общепринятая модель терапии акне с использованием топических антибиотиков оказывает прямое влияние на развитие устойчивости $P$. acnes в популяции (уровни устойчивости коррелируют с уровнями использования антибиотиков). И избирательное подавление микроорганизмов может вызвать увеличение количества патогенных бактерий, более агрессивных, чем $P$. acnes, что, в свою очередь, заставляет задуматься над необходимостью пересмотра стратегий лечения для предотвращения дальнейшего роста антибиотикорезистентности $P$. acnes.

В этой связи Всемирный альянс по улучшению результатов терапии больных с акне (Global Alliance Acne Treatment) рекомендует использовать комбинацию топических ретиноидов и бензоила пероксида как терапию первой линии для большинства пациентов с акне [11]. Антибиотики включают в схемы терапии больных лишь при средней и среднетяжелой степени тяжести акне. В случае легкого течения рекомендуется ограничиваться использованием топических ретиноидов совместно с бензоила пероксидом [11].

Бензоила пероксид, известный российскому дерматологу как активное действующее вещество фрирменного препарата Базирон АС, - средство с выраженным дезинфицирующим и широким спектром противомикробного действия, значительно превосходящим по эффективности антибактериальные препараты [1, 12-14]. Эффрективность бензоила пероксида обусловлена индукцией внутриклеточного оксидативного стресса, который приводит к гибели бактериальной клетки в результате высвобождения большого количества активного кислорода.

Универсальный механизм инициации бензоила пероксидом перекисной оксидации, приводящий к гибели клетки, обусловливает отсутствие даже потенциальной возможности формирования резистентности в будущем как у $P$. acnes, так и у других бактерий. Этот факт подтверждается тем, что на протяжении более чем полувекового использования бензоила пероксида в различных отраслях медицины к нему не было зарегистрировано ни одного случая резистентности микрооорганизмов. Важно отметить также и то немаловажное обстоятельство, что применение бензоила пероксида не индуцирует формирование антибиотикорезистентности у других микроорганизмов [14-16].
Тактика врача по ограничению распространения антибиотикорезистентности $\boldsymbol{P}$. acnes [14]

1. Избегать монотерапии или поддерживающей терапии антибиотиками.

2. При отсутствии ответа на терапию антибиотиками ограничивать продолжительность лечения 6-12 нед.

3. Вместо топических антибиотиков использовать в качестве средств наружной терапии препараты с выраженной антимикробной активностью широкого спектра действия - бензоила пероксида.

4. Избегать одновременного назначения топических и пероральных антибиотиков без бензоила пероксида.

5. Применять комбинированные препараты на основе ретиноида и бензоила пероксида.

6. Применять топические ретиноиды совместно или без бензоила пероксида для поддерживающей терапии.

Использование бензоила пероксида в виде монотерапии или в комбинации с топическими ретиноидами может служить эффективным и хорошим выбором для пациентов с резистентными штаммами $P$. acnes, в свою очередь, уменьшая формирование дальнейшей резистентности. Топические ретиноиды, используемые для лечения больных акне, проявляют как противовоспалительную, так и антикомедональную активность [17]. Поэтому они высокоэффективны и при наличии воспалительных элементов акне, и при их отсутствии $[18,19]$.

Другой возможностью повышения эффективности терапии при акне и преодоления антибиотикорезистентности $P$. acnes явился подбор оптимальных концентраций действующих веществ - ретиноида (адапален) и бензоила пероксида в готовой лекарственной форме - комбинированный препарат Эффрезел (производитель - компания Галдерма), позволяющий добиться бо́льшей клинической эфффективности, чем при использовании каждого средства в отдельности, за счет «эффректа синергизма» [20-22].

Примечательным является отмеченное свойство синергетической комбинации адапален/бензоила пероксида - эффрективность препарата тем выше, чем больше воспалительных папулопустулезных элементов до начала лечения [20]. Анализ этого, на первый взгляд удивительного, факта делает очевидным, что тяжесть течения акне во многом обусловлена степенью обсемененности кожного покрова в очаге поражения антибиотикорезистентными патогенными формами P. acnes и других микроорганизмов [21]. Быстрое антимикробное и противовоспалительное действие комбинации ретиноида и бензоила пероксида позволяет в кратчайшие сроки элиминировать бо́льшую часть штаммов с патогенными свойствами, что клинически становится более заметным, чем в случае терапии более легких форм заболевания. 


\section{Заключение}

Несмотря на то что антибактериальные препараты играют важную роль в терапии акне, увеличение регистрируемых случаев антибиотикорезистентных штаммов $P$. acnes должно стать поводом для беспокойства профессионального дерматологического сообщества и послужить стимулом к изменению алгоритмов лечения этого заболевания.

Кроме того, индуцированная антибиотикорези стентность $P$. acnes приводит не только к ослаблению клинического эффректа в ответ на проводимую терапию акне, но и к передаче антибиотикорезистентных свойств более патогенным микроорганизмам, что мо- жет создавать реальную угрозу для жизни пациента, ввиду способности антибиотикорезистентных штаммов осложнять обычное течение различных болезней, которые могут возникнуть у человека в процессе его жизни.

Ограничение частоты и продолжительности использования антибактериальных препаратов и применение вместо них эфффективных препаратов на основе бензоила пероксида (Базирон АС, Эфффезел) позволит свести к минимуму развитие резистентности микроорганизмов при сохранении эффеективности терапии в процессе лечения воспалительного и невоспалительного акне.

\section{Литература}

1. Samtsov A.V. Akne i akneformnye dermatozy. M: YuTKOM, 2009; 288 [Самцов А.В. Акне и акнеформные дерматозы. М: ЮТКОМ, 2009; 288.]

2. Burkhart $C$., Burkhart $C$. Expanding the microcomedone theory and acne therapeutic: P. acnes biofilm produses biological glue that holds corneocytes together to form plug. J Am Acad Dermatol 2007; 67: $722-744$

3. Webster G.F. Acne vulgaris. BMJ 2002; 325 (7362): $475-479$.

4. Leyden J.J., Del Rosso J.Q., Webster G.F. Clinical considerations in the treatment of acne vulgaris and other inflammatory skin disorders: focus on antibiotic resistance. Cutis 2007; 79 (6 Suppl): 9-25.

5. Crawford W.W., Crawford I.P., Stoughton R.B. et al. Laboratory induction and clinical occurrence of combined clindamycin and erythromycin resistance in Corynebacterium acnes. J Invest Dermatol 1979; 72 (4): $187-190$.

6. Cunliffe W.J., Holland K.T., Bojar R. et al. A randomized, double-blind comparison of a clindamycin phosphate/benzoyl peroxide gel formulation and a matching clindamycin gel with respect to microbiologic activity and clinical efficacy in the topica treatment of acne vulgaris. Clin Ther 2002; 24 (7): $1117-1133$

7. Leyden J., Kaidbey K., Levy S.F. The combination formulation of clindamycin 1\% plus benzoyl peroxide $5 \%$ versus 3 different formulations of topical clindamycin alone in the reduction of Propionibacterium acnes. An in vivo comparative study. Am J Clin Dermatol 2001; 2: 263-266.
8. Schafer F. Fich F., Lam M. et al. Antimicrobial susceptibility and genetic characteristics of Propionibacterium acnes isolated from patients with acne. Int J Dermatol 2013; 52 (4): 418-425.

9. Harkaway K.S., McGinley K.J., Foglia A.N. et al. Antibiotic resistance patterns in coagulase-negative staphylococci after treatment with topical erythromycin, benzoyl peroxide, and combination therapy. $\mathrm{Br} \mathrm{J}$ Dermatol 1992; 126 (6): 586-590.

10. Vowels B.R., Feingold D.S., Sloughfy C. et al. Effects of topical erythromycin on ecology of aerobic cutaneous bacterial flora. Antimicrob Agents Chemother 1996; 40 (11): 2598-2604.

11. Nast A., Dreno B., Bettoli V. et al. European Evidencebased (S3) Guidelines for the Treatment of Acne. J Eur Acad Dermatol Venereol 2012; 26 (Suppl. 1): $1-29$.

12. Mills 0. Jr., Thornsberry C., Cardin C.W. et al. Bacterial resistance and therapeutic outcome following three months of topical acne therapy with $2 \%$ erythromycin gel versus its vehicle. Acta Derm Venereol 2002; 82 (4): 260-265.

13. Araviyskaya E.R., Krasnosel'skikh T.V., Sokolovskiy E.V. Akne. V: Kozhnyy zud. Akne. Urogenital'naya khlamidiynaya infektsiya / pod redaktsiey E.V. Sokolovskogo. SPb: Sotis, 1998; 68-100. [Аравийская Е.Р., Красносельских Т.В., Соколовский Е.В. Акне. В: Кожный зуд. Акне. Урогенитальная хламидийная инфекция / Под ред. Е.В. Соколовского. СПб: Сотис, 1998; 68-100.]

14. Rosen T. Antibiotic resistance: an editorial review with recommendations. J Drugs Dermatol 2011; 10 (7): $724-733$.
15. Burke B., Eady E.A., Cunliffe W.J. Benzoyl peroxide versus topical erythromycin in the treatment of acne vulgaris. Br J Dermatol 1983; 108: 199-204.

16. Swinyer L.J., Baker M.D., Swinyer T.A., Mills O.H. A comparative study of benzoyl peroxide and clindamycin phosphate for treating acne vulgaris. Br J Dermatol 1988; 199: 615-622.

17. Gollnick H., Cunliffe W., Berson D. et al. Management of acne: a report from a Global Alliance to Improve Outcomes in Acne. J Am Acad Dermatol 2003; 49 (1 Suppl): S1-37.

18. Thiboutot D.M., Shalita A.R., Yamauchi P.S. et al. Adapalene gel, $0.1 \%$, as maintenance therapy for acne vulgaris: a randomized, controlled, investigatorblind follow-up of a recent combination study. Arch Dermatol 2006; 142 (5): 597-602.

19. Leyden J., Thiboutot D.M., Shalita A.R. et al. Comparison of tazarotene and minocycline maintenance therapies in acne vulgaris: a multicenter, doubleblind, randomized, parallel-group study. Arch Dermatol 2006; 142 (5): 605-612.

20. Feldman S.R., Tan L., Poulin Y. et al. The efficacy of adapalene-benzoyl peroxide combination increases with number of acne lesions. J Am Acad Dermatol 2011; 64 (6): 1085-1091.

21. Leyden J.J., Preston N., Osborn C., Gottschalk R.W. Invivo effectiveness of adapalene $0.1 \% /$ benzoyl peroxide $2.5 \%$ gel on antibiotic-sensitive and resistant Propionibacterium acnes. J Clin Aesthet Dermatol 2011; 4 : $22-26$.

22. Gold L.S., Tan J., Cruz-Santana A. et al. A North American study of adapalene-benzoyl peroxide combination gel in the treatment of acne. Cutis 2009; 84: $110-116$.

об авторе:

Н.Н. Мурашкин - д.м.н., профессор кафедры инфекционных болезней и эпидемиологии с курсом дерматовенерологии МАОУ ВПО «КМММИВСО» 